\title{
Exposure to benzene in Turkey between 1983 and 1985: a haematological study on 231 workers
}

\author{
M AKSOY, ${ }^{1}$ S ÖZERIŞ, ${ }^{2}$ H SABUNCU, ${ }^{3}$ Y INANICI, ${ }^{2}$ R YANARDA ${ }^{2}$ \\ From the Department of Biology, ${ }^{1}$ Gebze, Kocaeli, Research Institute for Basic Sciences, Scientific and \\ Technical Research Council of Turkey; and Engineering Faculty ${ }^{2}$ and Department of Public Health, ${ }^{3}$ Istanbul \\ University, Çapa-Istanbul, Turkey
}

\begin{abstract}
A study was performed to determine the content of benzene in the air and solvents and thinners used by 231 workers in $\mathbf{4 0}$ small or large workplaces in Istanbul and Izmit. The benzene value in the air of a tyre cord manufacturing factory where two cases of acute leukaemia were recorded in a six year period was $110 \mathrm{ppm}$. In nine of 47 thinners $(19.1 \%)$ the benzene content ranged between $0 \%$ and $6.4 \%$ whereas it was between $0.7 \%$ and $7.64 \%$ in 26 of 34 solvents used. A haematological study on 231 workers showed that there were mild abnormalities in 14 workers including leucopaenia in nine $(3.9 \%)$, thrombocytopaenia in four $(2 \cdot 16 \%)$, and pancytopaenia in one $(0.54 \%)$. This study shows that despite the considerable decrease in the content of benzene in the solvents and thinners available in Istanbul and Izmit the percentages of benzene in most of the materials are still above permissible limits.
\end{abstract}

The effects of chronic benzene toxicity are well known and include leucopaenia, thrombocytopaenia, aplastic anaemia, chromosomal aberrations and leukaemia. ${ }^{1-3}$ In 1971 one of the present authors and his associates published the results of a haematological study on 217 workers chronically exposed to benzene in Istanbul. ${ }^{2}$ In that study haematological abnormalities attributable to chronic benzene toxicity were detected in 51 of 217 workers (23.5\%). Additionally, in this period (1962-71) numerous cases of aplastic anaemia and malignant lymphoma due to the use of benzene have been reported, mostly from the same workplaces where the above mentioned studies were performed. ${ }^{2-5}$ Since 1969 there has been a gradual prohibition and discontinuation of the use of benzene in Istanbul. Due to this fact, a striking decrease in the number of the victims of chronic benzene toxicity has been recorded since 1975. ${ }^{145}$

We thus decided to perform a haematological study on 231 workers in Istanbul and Izmit, a town close to Istanbul, where solvents, thinners, and similar materials were used.

Accepted 10 November 1986

\section{Material and methods}

Between 1983 and 1985, 231 workers employed in 40 workplaces in Istanbul and Izmit, consisting of small and large shoe manufacturing plants, leather workshops, repair plants in airport and dockyards, automotive plants, farm vehicle manufacture and repair plants, and tyre cord and tyre fabric manufacturing plants were studied haematologically. All except four were men and their ages ranged from 14 to 57 (mean 32.7). The duration of exposure was between one month and 40 years (mean 8.8 years). In eight workers the duration of exposure was less than one year. Blood samples were collected in heparinised bottles and two peripheral blood smears were prepared from each person. Blood counts were determined with either a Coulter counter ZF or a Technicon 102. Platelet counts were estimated with a Coulter thrombocytometer or by the Brecher Cronkite method ${ }^{6}$; blood films were stained by the May Grünwald Giemsa method. Benzene in solvents, thinners, air, dyes, and lacquers were determined by gas chromatography. ${ }^{7}$ In this method three columns were used for analysis. The first column, $10 \mathrm{ft} \times 1 / 8^{\prime \prime}$ stainless steel, was packed with $5 \%$ Carbowax, 4000 TPA 
Table 1 Benzene concentration in 108 materials collected in 40 workshops in Istanbul and Izmit between 1983 and 1985

\begin{tabular}{|c|c|c|c|c|}
\hline Materials & No of specimens & Benzene (\%) & Mean benzene (\%) & $\begin{array}{l}\text { Percentage of specimens containing? } \\
\text { more than } 1 \% \text { of benzene }\end{array}$ \\
\hline $\begin{array}{l}\text { Air } \\
\text { Thinner } \\
\text { Solvent } \\
\text { Dye } \\
\text { Lacquer }\end{array}$ & $\begin{array}{r}13 \\
47 \\
34 \\
9 \\
5\end{array}$ & $\begin{array}{l}0-110 \mathrm{ppm} \\
0-6.6 \\
0.7-7.64 \\
0-1.46 \\
0-\text { very little }\end{array}$ & $\begin{array}{l}0.73 \\
0.73 \\
2.88 \\
0.32\end{array}$ & $\begin{array}{r}7 \cdot 7 \\
19 \cdot 1 \\
76 \cdot 4 \\
11 \cdot 1\end{array}$ \\
\hline
\end{tabular}

Table 2 Haematological data obtained in 231 workers employed in 40 workshops in Istanbul and Izmit

\begin{tabular}{|c|c|c|c|c|c|}
\hline & $\begin{array}{l}H b \\
(g / d l)\end{array}$ & $\begin{array}{l}P C V \\
(\%)\end{array}$ & $\begin{array}{l}R B C \\
\left(10^{12} / l\right)\end{array}$ & $\begin{array}{l}W B C \\
\left(10^{9} / l\right)\end{array}$ & $\begin{array}{l}\text { Platelets } \\
\left(10^{9} / \mathrm{l}\right)\end{array}$ \\
\hline $\begin{array}{l}\text { No of workers studied } \\
\text { Upper value } \\
\text { Lowest value } \\
\text { Mean value } \\
\text { Standard deviation }\end{array}$ & $\begin{array}{r}231 \\
16 \cdot 4 \\
10 \cdot 1 \\
13 \cdot 5 \\
\pm 0 \cdot 7\end{array}$ & $\begin{array}{c}231 \\
57 \\
36 \\
44 \cdot 0 \\
\pm 2 \cdot 1\end{array}$ & $\begin{array}{r}226 \\
5 \cdot 8 \\
3 \cdot 6 \\
4 \cdot 8 \\
\pm 0 \cdot 2\end{array}$ & $\begin{array}{r}231 \\
14 \cdot 8 \\
3 \cdot 1 \\
6 \cdot 9 \\
\pm 1 \cdot 3\end{array}$ & $\begin{array}{l}186 \\
410 \\
117 \\
224 \\
\pm 40 \cdot 0\end{array}$ \\
\hline than normal & $20(8 \cdot 7)$ & $32(13 \cdot 86)$ & $24(10.6)$ & $10(3 \cdot 9)$ & $5(2 \cdot 16$ \\
\hline
\end{tabular}

Table 3 Differential counts in 186 workers using materials containing benzene in Istanbul and Izmit

\begin{tabular}{|c|c|c|c|c|c|c|}
\hline & $\begin{array}{l}\text { Polymorpho- } \\
\text { nuclear } \\
\text { neutrophils } \\
(\%)\end{array}$ & $\begin{array}{l}\text { Band form } \\
(\%)\end{array}$ & $\begin{array}{l}\text { Lymphocytes } \\
(\%)\end{array}$ & $\begin{array}{l}\text { Monocytes } \\
(\%)\end{array}$ & $\begin{array}{l}\text { Eosinophils } \\
(\%)\end{array}$ & $\begin{array}{l}\text { Basophils } \\
(\%)\end{array}$ \\
\hline $\begin{array}{l}\text { Range } \\
\text { Mean value } \\
\text { SD } \pm\end{array}$ & $\begin{array}{l}40-74 \\
62 \cdot 8 \\
4 \cdot 3\end{array}$ & $\begin{array}{l}0-5 \\
1 \cdot 8 \\
0 \cdot 7\end{array}$ & $\begin{array}{l}16-58 \\
35 \cdot 1 \\
2 \cdot 6\end{array}$ & $\begin{array}{l}0-14 \\
4 \\
1 \cdot 6\end{array}$ & $\begin{array}{l}0-12 \\
2 \cdot 7 \\
0 \cdot 8\end{array}$ & $\begin{array}{ll}0-4 & 0 \\
0.2 & \text { 음 } \\
0.2 & \end{array}$ \\
\hline $\begin{array}{l}\text { No }(\%) \text { of workers with abnormal } \\
\text { values }\end{array}$ & $1(0 \cdot 5)$ & 0 & $1(0 \cdot 5)$ & $8(4 \cdot 3)$ & $5(2 \cdot 7)$ & $3(1 \cdot 6) \frac{\overline{\mathrm{Q}}}{2}$ \\
\hline
\end{tabular}

$80 / 100$ mesh Firebrick. The second column, $20 \mathrm{ft} \times$ $1 / 8^{\prime \prime}$ stainless steel, was packed $20 \%$ SE 30 Chromosorp P 60:80 mesh AW. The third column, 20ft $\times 1 / 8^{\prime \prime}$ stainless steel, was packed with $10 \%$ SP-1000, 80/100 mesh Supelcoport.

\section{Case reports}

Case 1-A 23 year old worker with 28 months exposure to benzene containing solvents and thinners in a modern tyre cord manufacturing plant developed acute myeloblastic leukaemia. He had a severe pancytopaenia and a hypercellular bone marrow with $71 \%$ myeloblasts associated with Auer's rod. The working conditions were good and the workplace was large and properly ventilated. The concentration of benzene measured by gas chromatography in one part of the plant was $110 \mathrm{ppm}$ and in one of the solvents used in an auxiliary repair shop the benzene content was $5.9 \%$.

Case 2-A 30 year old worker with four years exposure to benzene in the factory mentioned above developed acute lymphoblastic leukaemia. He had severe pancytopaenia and a hypocellular bone må row with $36 \%$ lymphoblasts.

Case 3-A 42 year old worker with five yea:5 exposure to benzene containing solvents and thinness developed acute myelomonocytic leukaemia. He had severe pancytopaenia with a mildly hypocellular bone marrow associated with $25 \%$ myeloblasts and $51 \%$ atypical monocytes. In the solvent and thinner used one section of the plant the benzene contents were $7 \cdot 4 \%$ and $4 \%$ respectively.

Case 4-A 48 year old worker with 15 yeafs exposure to benzene containing solvents and thinners in a large automotive plant developed Hodgkin's disease. He had cervical lymphadenopathy and mita hepatosplenomegaly. The results of a pathologica study showed Hodgkin's disease with lymphocyto predominance. The solvent and thinner containgd $3 \cdot 1 \%$ and $6 \cdot 6 \%$ of benzene.

Case 5-An 18 year old worker in a large shoe manufacturing plant developed axillary and inguinal lymphadenopathy after two years exposure to befo zene. Pathological examination of one of the lymp nodes showed a poorly differentiated lymphoma. In 
one of the solvents used the benzene content was $6.9 \%$.

\section{Results}

The benzene content of 108 materials used in 40 workshops are summarised in table 1 . In only one of 13 air samples was the benzene content more than 1 ppm; in this sample it was $110 \mathrm{ppm}$. In nine of 47 thinners $(19 \cdot 1 \%)$ the benzene value was more than $1 \%$, ranging to $6 \cdot 6 \%$. Similarly, 26 of 34 solvents $(76.4 \%)$ contained more than $1 \%$ of benzene ranging between $1 \cdot 1 \%$ and $7 \cdot 64 \%$. By contrast, in only one of nine samples of dyes was the benzene content more than $1 \%$. Five lacquers contained no benzene. Additionally, in toluene and heptane samples the amount of benzene was $2 \cdot 8$ and $4 \cdot 2 \%$ respectively.

Table 2 gives the results of a haematological study carried out on 231 apparently healthy workers. The haemoglobin content ranged between $10 \cdot 1$ and $16 \cdot 4$ $\mathrm{g} / \mathrm{dl}$ (mean: $13.51 \mathrm{~g} / \mathrm{dl}, \mathrm{SD} \pm 0.74$ ) and only in 20 workers $(8 \cdot 7 \%)$ was the haemoglobin level less than $12 \mathrm{~g} / \mathrm{dl}$. The PCV ranged between 0.36 and $0.571 / 1$ (mean: 0.44, SD $\pm 0 \cdot 19$ ); the red cell counts were between 3.6 and $5.8 \times 10^{12} / 1$ (mean: $4.81 \times 10^{12} / 1$, $\mathrm{SD} \pm 2 \cdot 10)$ and the white cell counts ranged between $3.1 \times 10^{9} / 1$ and $14.8 \times 10^{9} / 1$ (mean: $6.9 \times 10^{9} / 1$, $\mathrm{SD} \pm 1 \cdot 26)$. In nine workers $(3.9 \%)$ the leucocyte counts were less than $4 \times 10^{9} / 1$. Platelet counts performed in 186 workers were between 117 and $410 \times$ 109/1 (mean: $224 \times 10^{9} / 1, \mathrm{SD} \pm 40.023$ ); counts less than $150 \times 10^{9} / 1$ were found in four individuals $(2 \cdot 2 \%)$. Pancytopaenia was observed in only one worker $(0.54 \%)$. On the other hand, the results of the differential counts in 186 workers showed few changes with monocytosis in eight $(4.3 \%)$, eosinophilia in five $(1.6 \%)$, and basophilia in three $(1 \cdot 6 \%)$ (table 3$)$.

\section{Comment}

As may be seen in table $1,76.4 \%$ of the solvents and $19 \cdot 1 \%$ of the thinners used in 40 small or large workplaces in Istanbul and Izmit contained more than 1\% of benzene; the range was between $0.7 \%$ and $7.64 \%$ (mean: $2.8 \%$ ) in Istanbul and $0 \%$ and $6.6 \%$ (mean: $0.73 \%$ ) in Izmit. If we compare these results with those of the materials used between 1970 and 1972 there is a significant but not sufficient decrease in the content of benzene in the materials used in the work- shops in Istanbul and Izmit. At that time, the benzene content in the solvents used ranged between $0 \%$ and $88 \%$ (mean: $23 \cdot 15 \%$ ) and in the thinners between $0 \%$ and $70.6 \%$ (mean: 30.7\%). (I Topuzoğlu, unpublished data). Parallel to the fall in the benzene content in the solvents and thinners used between 1983 and 1985, a significant decrease in the haematological abnormalities attributable to this chemical was observed in 231 workers employed in the workplaces described above. One the other hand, the study performed among 217 workers heavily exposed to benzene in Istanbul showed that $51(23.4 \%)$ had haematological abnormalities including leucopaenia, thrombocytopaenia, pancytopaenia and the pseudoPelger Huet anomaly. ${ }^{2}$ By contrast, other haematological alterations such as leucopaenia, thrombocytopaenia, and pancytopaenia were relatively uncommon. The differences in the proportion of haematological abnormalities in the two studies is obviously due to the decrease in benzene content in the material used. Despite this, continuance of haematological abnormalities in workers in Istanbul and Izmit and the occurrence of five cases of acute leukaemia and malignant lymphoma in the same workshops clearly show that the deleterious effects of benzene, even in low percentages, continue in Istanbul and Izmit. Interestingly, four of these cases mentioned above had only a short duration of exposure to benzene, between two and four years.

This study was supported by a grant from the Scientific and Technical Research Council of Turkey.

\section{References}

1 Aksoy M. Benzene: leukaemia and malignant lymphoma. Topical Review in Haematology 1982;2:105-39.

2 Aksoy M, Dinçol K, Erdem Ş, Dinçol G. Haematological effects of chronic benzene poisoning in 217 workers. Br J Ind Med 1971;28:296-302.

3 Aksoy M, Dinçol K, Erdem Ş, Akgün T, Dinçol G. Details of blood changes in 32 patients with pancytopaenia associated with long term exposure to benzene. $\mathrm{Br} J$ Ind Med 1972;29:56-65.

4 Aksoy M. Different types of malignancies due to occupational exposure to benzene: a review of recent observations in Turkey. Environ Res 1980;23:181-90.

5 Aksoy M. Malignancies due to occupational exposure to benzene. Am J Ind Med 1985;7:395-402.

6 Brecher G, Cronkite EP. Morphology and enumeration of human platelets. $J$ Appl Physiol 1950;3:365-77.

7 White LD, Taylor A, Mauer PA, Kupel RE. A convenient optimized method for the analysis of selected solvent vapors in the industrial atmosphere. Am Ind Hyg Assoc J 1971;31:225. 